ISBN: 978-602-73955-3-4
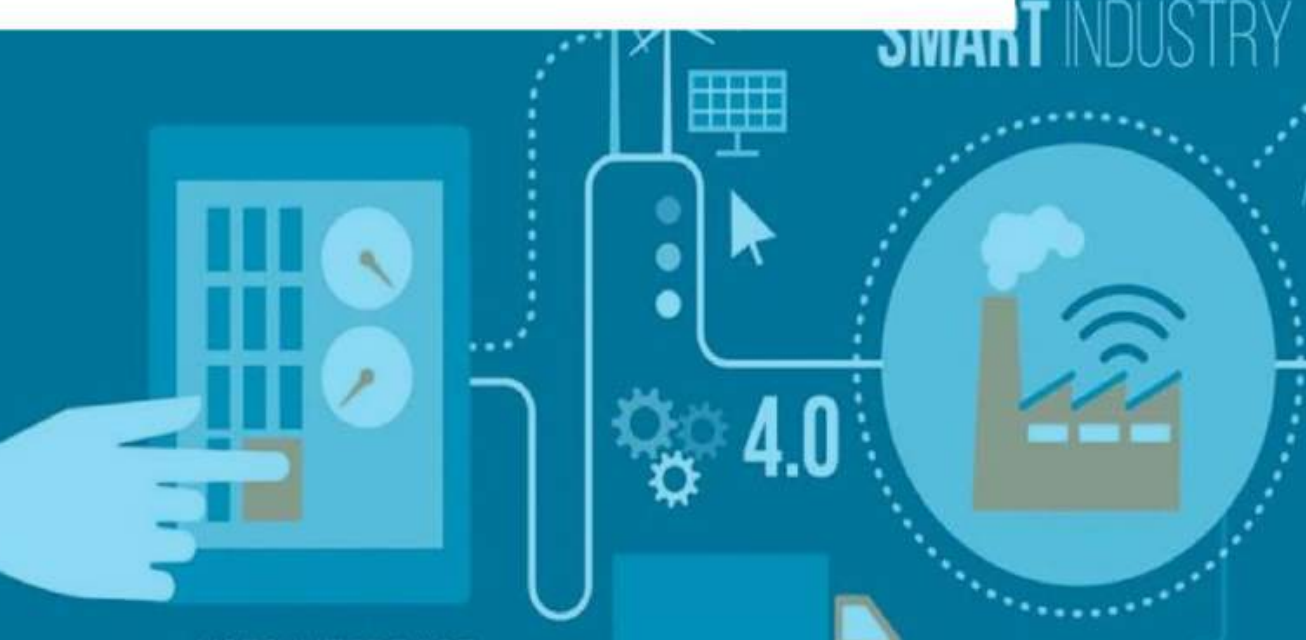

USER NIERFACE
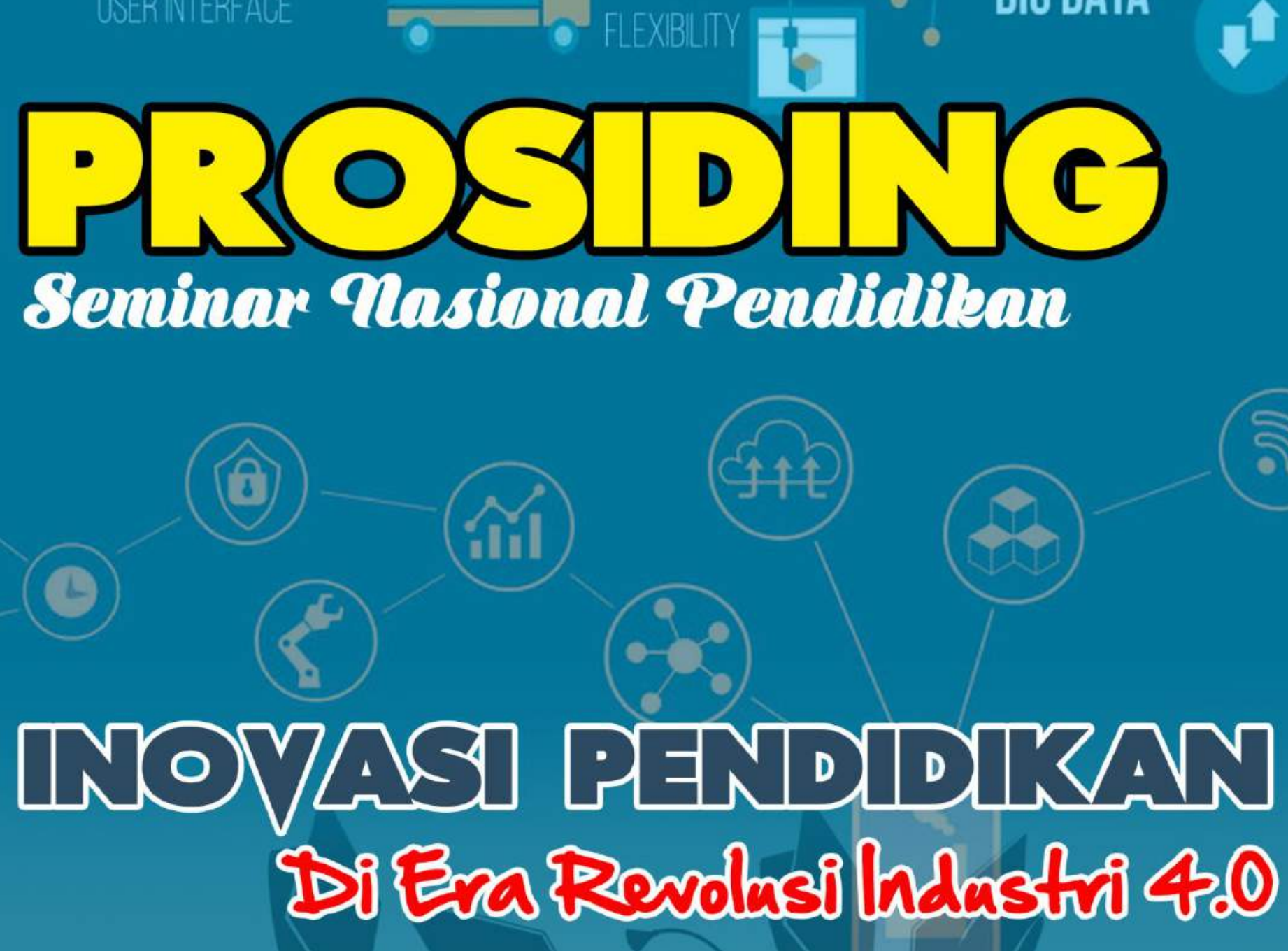

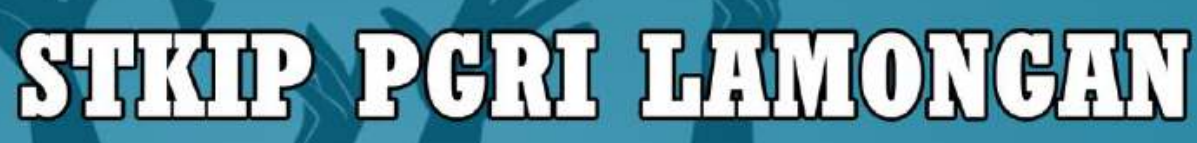

13 Agastus 2018 


\section{SEMINAR NASIONAL PENDIDIKAN}

Prosiding Seminar Nasional Pendidikan: Inovasi Pendidikan di Era Revolusi Industri 4.0

Lamongan, 13 Agustus 2018 Di Aula STKIP PGRI Lamongan

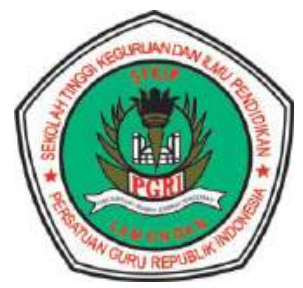

Penerbit:

STKIP PGRI LAMONGAN

Jalan Sunan Giri Nomor 35 Lamongan, 0322-321493 


\section{SEMINAR NASIONAL PENDIDIKAN}

Prosiding Seminar Nasional Pendidikan: Inovasi Pendidikan di Era Revolusi Industri 4.0

CSTKIP PGRI Lamongan

ISBN: 978-602-73955-3-4

\begin{tabular}{|c|c|}
\hline Pelindung & : Ketua STKIP PGRI Lamongan \\
\hline Pembina & $\begin{array}{l}\text { 1. Dr. Sutarum, M.Si (Wakil Ketua I STKIP PGRI Lamongan) } \\
\text { 2. Dr. Ahmad Sidi, M.Si (Wakil Ketua II STKIP PGRI Lamongan) }\end{array}$ \\
\hline Penanggungjawab & $\begin{array}{l}\text { 1. Hadi Suryanto, ST., M.Pd (Ketua P3M) } \\
\text { 2. Dra. Ninies Eryadini, M.Pd (Kaprodi Pendidikan Ekonomi) } \\
\text { 3. Nur Fithriya Wijiastutik, S.Pd., M.Pd (Kaprodi PPKn) }\end{array}$ \\
\hline
\end{tabular}

Ketua Panitia $\quad$ : Dr. Abd. Ghofur, S.Pd., M.Pd

Sekretaris $\quad$ : Durrotun Nafisah, S.Pd., M.Pd

\section{Reviewer:}

Dr. Askuri, MA (ICRS UGM Yogyakarta, Universitas ‘Aisyiah Yogyakarta)

Dr. Yetursance Y. Manafe, MT (Universitas Nusa Cendana Kupang, NTT)

Dra. Ratna Nurdiana, MM (STKIP PGRI Lamongan)

Hurip Tjahjono, SH., MH (Badan Penelitian dan Pengembangan Daerah Kabupaten Lamongan)

\section{Editor:}

Hadi Suryanto, ST., M.Pd

Yayuk Chayatun Machsunah, S.Sos., M.Pd

Nur Fithriya Wijiastutik, S.Pd., M.Pd

Ety Youhanita, S.Pd., M.Pd

\section{Layout Setting:}

Kuswanto S.Kom., MM

Imam Syafi'i, S.Sos

Cetakan : Kesatu, Agustus 2018

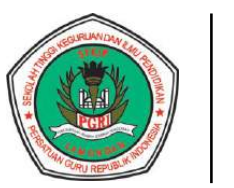

\section{Penerbit:}

STKIP PGRI Lamongan

Jl. Sunan Giri Nomor 35 Lamongan,

Phone (0322) 321493 


\section{DAFTAR ISI}

Sampul

Halaman Judul

Balik Halaman Judul

Kata Pengantar

Daftar isi

Template Penulisan

\section{Artikel Narasumber}

Persepsi Guru dalam Pola Integrasi Islam dalam Pendidikan Sains di Sekolah-sekolah Islam;

Askuri, Joel C. Kuipers

Penerapan Pembelajaran Collaborative Experential Learning pada Mata

Kuliah Perencanaan Pembelajaran;

Yetursance Y. Manafe

Industrial Revolution 4.0 and The Education Concept In The Digital Era;

Ratna Nurdiana

\section{Artikel Presenter}

Pengembangan Media Visual pada Mata Pelajaran PPKn;

Ety Youhanita, Abd. Ghofur

Pengaruh Pengalaman Kewirausahaan terhadap Sikap Kewirausahaan

Mahasiswa STKIP PGRI Lamongan;

Evi Aulia Rachma

The Influence of Teacher Competence on Learning Achievement of SMK PGRI 3 Lamongan Students;

Kuswanto

Strategi Pembelajaran pada Mata Kuliah Kewirausahaan di Perguruan

Tinggi;

Yayuk Chayatun Machsunah

Inovasi Pembelajaran untuk Memberi Makna Serta Mengubah Perilaku dan Daya Pikir Peserta Didik;

Ahmad Sidi 
Analisis Produktivitas Pengrajin terhadap Tingkat Pendapatan Pengrajin Anyaman Bambu;

Vita Lidyawati, Ratna Nurdiana, Ninies Eryadini, Abd. Ghofur

Penggunaan "SIKU" Sistem Informasi Keuangan Dalam Manajemen $88-92$ Keuangan Di Lembaga PAUD IT Cendekia Lamongan;

Desinta Prasetia Nesti, Ratna Nurdiana, Ninies Eryadini, Abd. Ghofur

Penerapan Metode Demonstrasi Dengan "Kartu Aksi" dalam Meningkatkan

Kemampuan Menyusun Laporan Keuangan;

Sri Utami, Ratna Nurdiana, Ninies Eryadini, Abd. Ghofur

Pengaruh Pergaulan Teman Sebaya Terhadap Motivasi Bekerja Remaja;

98-103

Nurul Mustofa, Ratna Nurdiana, Ninies Eryadini, Abd. Ghofur

Penggunaan Model Kooperatif Tipe STAD Untuk Meningkatkan 104-110 Kemampuan Menganalisis Materi Peran Serta Dalam Organisasi;

Nur Fadilah, Sutarum, Ninies Eryadini, Nur Fithria Wiji Astutik

Pengaruh Penggunaaan Media Sosial Terhadap Karakter Santun Remaja Di Dusun Ngelo Desa Menongo Kecamatan Sukodadi;

Meilani Dwi Anggraini, Sutarum, Ninies Eryadini, Nur Fithria Wiji Astutik

Penggunaan Metode Role Playing untuk Meningkatkan Kemampuan Mengimplementasi Materi persamaan Kedudukan Warga Negara;

Wahyu Rohmah Yussita, Sutarum, Ninies Eryadini, Ety Youhanita

Korelasi Antara Tingkat Pendidikan Orang Tua Dengan Perilaku Belajar $129-139$ Anak;

Setiyowati Mahardika, Sutarum, Ninies Eryadini, Ety Youhanita

Hubungan Antara Kompetensi Guru Sertifikasi Dengan Kualitas Pendidikan $140-148$ Karakter Siswa;

Ririn Ismawati, Endah Yuliani, Abd. Ghofur, Hadi Suryanto

Pengaruh Full Day School Terhadap Motivasi Belajar Siswa;

Fitri Imro'atus Solihah, H. Ahmad Sidi, Abd. Ghofur

Pengaruh Kondisi Sosial Ekonomi Orangtua Terhadap Keterampilan Afektif $154-159$ Siswa;

Avita Maya, Endah Yuliani, Abd. Ghofur, Yayuk Chayatun Machsunah

Pengaruh Status Sosial Orangtua Terhadap Prestasi Anak;

$160-166$

Zuhrotul Habibah, Endah Yuliani, Abd. Ghofur, Yayuk Chayatun Machsunah

Korelasi Antara Konformitas Teman Sebaya Terhadap Kemandirian Belajar Siswa;

Silvi Ana Suvlah, H. Ahmad Sidi, Abd. Ghofur, Nur Fithria Wiji Astutik

$167-172$ 
Penerapan Media Gambar Terhadap Kemampuan Bercerita Mata Pelajaran

$173-178$ PKN;

Ani Trisnawati, H. Ahmad Sidi, Abd. Ghofur, Hadi Suryanto

Pengaruh Pembelajaran Outdor Terhadap Kreativitas Siswa;

$179-186$

Dewi Hartatik, H. Ahmad Sidi, Abd. Ghofur, Hadi Suryanto 


\title{
PENGEMBANGAN MEDIA VISUAL PADA MATA PELAJARAN PPKn
}

\author{
Ety Youhanita' ${ }^{1)}$ Abd. Ghofur ${ }^{2}$ \\ ${ }^{1,2}$ STKIP PGRI Lamongan \\ Email: etyyouhanita@yahoo.com
}

\begin{abstract}
ABSTRAK
Penelitian ini bertujuan untuk mengetahui pentingnya media pembelajaran di dalam kelas, serta peningkatan hasil belajar peserta didik pada mata pelajaran PPKn. Jenis penelitian menggunakan penelitian pengembangan dengan model pengembangan ADDIE yang terdiri dari lima tahapan yaitu analysis, design, development, implementation dan evaluation. Subjek penelitian adalah peserta didik sekolah dasar kelas 6 sejumlah 40 orang kelas kontrol dan 40 orang kelas eksperimen. Instrumen pengumpulan data menggunakan metode dokumentasi, tes dan metode angket yang menggunakan skala likert dan uji-t. Hasil penelitian menunjukkan pada proses pengembangan media visual dibagi menjadi 5 tahap. Analisis adalah mengumpulkan semua dokumen penting dalam proses pembelajaran dikumpulkan dan dianalisis. Desain adalah membuat storyboard tentang media visual yang akan dikembangkan sesuai dengan tujuan pembelajaran yang ada pada silabus dan RPP. Pengembangan adalah mengembangan media visual sesuai dengan materi pembelajaran yang akan disampaikan. Penerapan adalah menerapkan media visual pada proses pembelajaran yang sudah direncanakan di kelas dan melakukan validasi pada ahli materi dengan tingkat penilaian $80 \%$ dengan kategori layak, validasi ahli media dengan tingkat penilaian $79 \%$ dengan kategori layak, validasi pada pendidik mata pelajaran PPKn dengan tingkat penilaian 93 dengan kategori sangat layak dan yang terakhir adalah uji coba pada kelompok validasi kengan penilaian sebanyak 95\% dengan kategori sangat layak.
\end{abstract}

Kata kunci: Pengembangan, media visual,model pengembangan ADDIE, mata pelajaran PPKn.

\begin{abstract}
This study aims to determine the importance of learning media in the classroom, as well as improving student learning outcomes in PPKn subjects. This type of research uses development research with ADDIE development model which consists of five stages, namely analysis, design, development, implementation and evaluation. The research subjects were 40th grade elementary school students in the control class and 40 in the experimental class. Data collection instruments using documentation methods, tests and questionnaire methods that use a Likert scale and t-test. The results showed that the visual media development process was divided into 5 stages. The analysis is collecting all important documents in the learning process collected and analyzed. Design is to make a storyboard about visual media that will be developed in accordance with the learning objectives contained in the syllabus and lesson plans. Development is developing visual media in accordance with the learning material that will be delivered. The application is to implement visual media in the learning process that has been planned in the classroom and validate the material experts with an $80 \%$ assessment level with a feasible category, validation of media experts with an assessment rate of $79 \%$ with a decent category, validation of PPKn subject educators with an assessment level 93 with a very feasible category and the last is a trial on the validation group with a $95 \%$ assessment with a very feasible category.
\end{abstract}

Keywords: Development, visual media, ADDIE development model, PPKn subjects.

\section{LATAR BELAKANG}

Sebanyak $98 \%$ informasi belajar yang ditangkap dan masuk ke otak peserta didik adalah melalui indra (Tileston,
2004). Pendapat Tileston juga didukung oleh hasil reset awal yang menyatakan bahwa lebih dari $87 \%$ peserta didik di kelas lebih suka belajar dengan belajar 
visual, ini artinya mayoritas peserta didik lebih banyak menggunakan gaya belajar visual dari pada gaya belajar yang lain.

Gaya belajar merupakan suatu kombinasi dari bagaimana ia menyerap, dan kemudian mengatur serta mengolah informasi berdasarkan pendapat DePorter \& Hernacki (2001). Sedangkan Nasution (2003) juga menyatakan bahwa gaya belajar atau learning style adalah cara berinteraksi dan menggunakan perangsang-perangsang yang diterimanya dalam proses belajar. Jadi gaya belajar adalah teknik belajar yang digunakan oleh peserta didik.

Oxford (2003) menyatakan bahwa gaya belajar merupakan sebuah pendekatan umum, misalnya auditori, analitik, atau visual, dimana peserta didik menggunakannya untuk mempelajari sesuatu. Gaya belajar merupakan salah satu faktor yang sangat penting untuk diperhatikan dalam proses belajar, karena gaya belajar dapat membantu peserta didik dalam proses menerima dan memahami informasi (materi pembelajaran) dari pendidik.

Umumnya gaya belajar dapat dibedakan menjadi tiga yaitu gaya belajar visual, gaya belajar auditorial dan gaya belajar kinestetik. Gaya belajar visual adalah gaya belajar dengan cara melihat, mengamati, memandang, dan sejenisnya. Gaya belajar auditorial adalah gaya belajar dengan cara mendengar. Gaya belajar kinestetik adalah gaya belajar dengan cara bergerak, bekerja dan menyentuh DePorter \& Hernacki (2013).

Ketiga gaya belajar yang telah dijelaskan pada paragraph sebelumnya sangat berpengaruh dalam menentukan strategi belajar peserta didik. Sesuai dengan pendapat Dale dalam Arsyad (2008) bahwa perolehan hasil belajar melalui indera pandang (visual) berkisar $75 \%$, indera dengar (auditorial) berkisar $13 \%$ dan indera lainnya (termasuk kinestetik) berkisar 12\%. Kesimpulannya hasil belajar yang menggunakan indera pandang (visual) lebih unggul dibandingkan dengan indera lainnya.

Gaya belajar visual lebih menitik beratkan peserta didik melalui penglihatan, sehingga metode pembelajaran yang harus digunakan bersifat visual. Salah satu metode pembelajaran yang bersifat visual adalah penggunaan media visual dalam proses pembelajaran. Media visual adalah media yang menitik beratkan indera penglihatan (Munadi, 2013). Media visual memiliki dua jenis pesan yaitu verbal dan nonverbal.

Pesan verbal-visual terdiri atas katakata (bahasa verbal) dalam bentuk tulisan, dan pesan nonverbal-visual adalah pesan yang dituangkan ke dalam simbol (Munadi, 2013). Proses pesan verbal maupun nonverbal merupakan sebuah 
proses komunikasi yang berisi pesan baik dalam bentuk bahasa maupun simbol melalui saraf peserta didik yang akan disampaikan pada penerima pesan.

Proses menyampaikan pesan dalam pembelajaran harus memperhatikan adanya komunikasi yang efektif. Komunikasi yang dapat diterima dan dapat dipahami dengan baik oleh peserta didik. Komunikasi yang dimaksud adalah bagaimana pendidik dapat berkomunikasi dalam menyampaikan materi pembelajaran yang bersifat teoritis, karena materi pembelajaran yang bersifat teoritis cenderung membosankan.

Materi pembelajaran yang bersifat teoritis membuat pendidik harus lebih kreatif dan jelas dalam menyampaiakan materi pembelajaran. Jika ditinjau dari proses pembelajaran di berbagai sekolah yang ada di sekitar kecamatan kedungpring, data hasil reset menunjukkan bahwa proses pembelajaran di sekolah dalam menyampaikan mata pelajaran PPKn rata-rata nilai ujian lebih rendah dari nilai pembelajaran yang lain, akan tetapi ada satu sekolah yang hampir $87 \%$ peserta didiknya nilai mata pelajaran PPKn sangat rendah yaitu SDN Negeri 1 Kedungpring.

Faktor rendahnya nilai ujian tersebut setelah dikaji lebih mendalam menyatakan bahwa pendidik mata pelajaran PPKn sekitar $85 \%$ menyatakan bahwa pendidik seringkali mengalami kesusahan dalam menemukan cara untuk membantu peserta didik dalam memahami gagasan materi yang rumit serta meningkatkan hasil belajar yang sesuai dengan standart hasil belajar yang telah ditentukan pada RPP.

Berdasarkan masalah yang terjadi pada proses pembelajaran mata pelajaran PPKn, maka harus diberikan alternatif solusi yang dapat menanggulangi masalah tersebut. Alternatif solusi yang harus diterapkan adalah dengan memberikan alat bantu yang sesuai dengan karakteristik materi pembelajaran yang bersifat teori, selain itu juga dapat sebagai solusi untuk membantu peserta didik dalam memahami gagasan materi yang rumit serta meningkatkan hasil belajar.

Alat bantu yang sesuai dengan masalah yang terjadi pada proses pembelajaran PPKn adalah dengan mengembangan media visual pada mata pelajaran PPKn, karena media visual selain berbentuk nyata juga dapat mengubah gagasan abstrak menjadi sebuah format yang lebih realistik. Media visual juga memungkinkan proses pembelajaran berpindah dari tingkat verbal menuju ke tingkat konkret abstrak dan bahkan menuju ke tingkat yang lebih konkret (visual) (Smaldino dkk, 2008).

\section{METODE PENELITIAN}

Pentingnya penggunaan media visual dalam menyampaikan mata pelajaran 
PPKn proses pengembangannya menggunakan model pengembangan ADDIE (analyze, design, development, implementation and evaluation). Model pengembangan ADDIE dipilih berdasarkan hasil reset pada mata pelajaran PPKn yang bertujuan untuk mengembangkan media dalam bentuk visual sekaligus dilakukan uji coba tingkat efektifitas penggunaanya.

Model pengembangan ADDIE diadaptasi dari model desain instruksional yang terdiri dari lima tahapan yaitu analisis (analysis), desain (design), pengembangan (development), imple-mentasi/eksekusi (implementation) dan evaluasi/umpan balik (evaluation) (Tegeh \& Kirna, 2010). Model ADDIE ada pada tahun 1990-an, model ini dikembangkan oleh Reiser dan Mollenda. Menurut Pribadi (2009) ADDIE merupakan satu model desain pembelajaran yang sifatnya lebih generik.

Adapun desain prosedur pengembangan dengan menggunakan model ADDIE ke lima tahapan menurut Mulyatiningsih (2012) dapat dilihat pada bagan berikut ini :

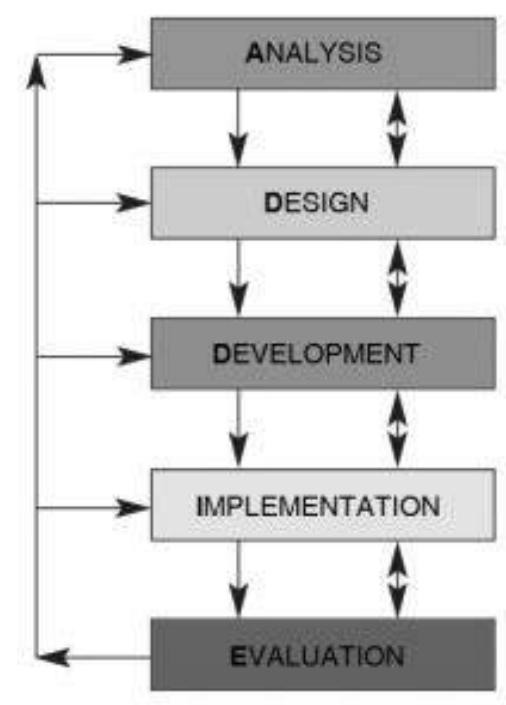

Tahap pertama adalah analisis. Tahap ini merupakan tahap awal sebelum membuat konsep pembelajaran. Pada tahap ini terbagi menjadi dua yaitu analisis kebutuhan dan analisis tugas pada peserta didik. Tahap analisis adalah sebuah tahap awal untuk menjelaskan kebutuhan apa saja yang dibutuhkan oleh peserta didik. Analisis kebutuhan berfungsi untuk menentukan kemampuan dasar yang harus dipelajari oleh peserta didik.

Sedangkan analisis tugas berfungsi untuk mengetahui dan mencari solusi dari masalah yang ada pada proses pembelajarana. Hasil dari kedua tahapan tersebut berupa karakteristik peserta didik, faktor pendukung dan penghambat proses belajar, karakteristik materi pembelajaran, isi pembelajaran, tujuan pembelajaran, karakteristik materi pembelajaran, dan semua hal yang berkaitan dengan kurikulum pembelajaran. 
Tahap kedua adalah desain atau rancangan. Desain yang akan dikembangkan harus sesuai dengan hasil analisis pada tahap pertama. Tahap desain yang pertama adalah merumuskan tujuan pembelajaran yang akan dicapai, menyusun konsep pembelajaran yang berbasis media visual, membuat kerangka struktur media visual, menentukan sistematikan penyajian materi dengan media visual, membuat storyboard pengembangan media visual, menyusun instrument penilaian pembelajaran berdasarkan tujuan pembelajaran dan menyusun instrument penilaian media visual.

Tahap ketiga adalah pengembangan. Pengembangan yang dimaksud adalah tindak lanjut dari tahap desain yang direalisasikan berbentuk media visual. Tahap pengembangan meliputi kegiatan mengumpulkan dan mengolah materi yang telah disiapkan ke dalam bentuk media visual, mengujicobakan media visual pada kelas uji coba, yang hasilnya dapat digunakan sebagai bahan acuan dalam penyempurnaan produk dan melakukan evaluasi formatif yang hasilnya berupa validasi pada ahli media dan ahli materi.

Tahap yang keempat adalah penerapan. Penerapan yang dimaksud adalah menerapkan hasil pengembangan yang sudah jadi dalam proses pembelajaran. Tahap penerapan meru- pakan tahapan yang paling penting, karena pada tahap ini semua hal yang telah disiapkan mulai dari tahap analisis, tahap desain (rancangan) dan tahap pengembangan yang sudah diatur dan ditata sesuai dengan perannya harus diperhatikan dalam proses penerapannya.

Adapun tujuan dari penerapan pengembangan media adalah sebagai alat bantu peserta didik dalam mencapai tujuan pembelajaran, sebagai alat bantu pendidik dalam mengatasi kesenjangan proses pembelajaran, dan sebagai alat bantu dalam menghasilkan output yang sesuai dengan standart pembelajaran. Tahap penerapan juga dilakukan evaluasi untuk mengetahui kelayan dan efektifitas media yang dikembangkan dengan dilakukan pretest dan posttes untuk memberikan umpan balik pada penerapnnya.

Tahap terakhir adalah tahap evaluasi. Evaluasi merupakan proses untuk melihat secara terperinci apakah media yang telah dikembangkan dan diterapkan pada proses pembelajaran sesuai dengan harapan atau tidak. Tahap evaluasi terbagi menjadi dua yaitu evaluasi internal dan evaluasi eksternal atau biasa dikenal dengan evaluasi formatif dan sumatif dari produk pengembangan. Selain kedua evaluasi tersebut evaluasi juga dilakukan pada setiap tahap pengembangan ADDIE.

Hasil evaluasi internal berupa perbaikan produk pengembangan, evaluasi 
internal berasal dari hasil catatan revisi validasi dari para ahli (media dan materi) dan dari peserta didik. Hasil evaluasi internal ini digunkan untuk menyempurnakan pengembangan media yang akan terapkan pada di kelas. Evaluasi eksternal berupa hasil dari uji coba media pada kelompok besar, dimana selain mengukur tingkat efektifitas media dalam meningkatkan hasil belajar juga mengukur tingkat ketercapai tujuan pembelajar dengan menggunakan media yang telah dikembangkan. Evaluasi eksternal dilakukan pada akhir program pembelajaran.

Penelitian dilakukan pada bulan April hingga Agustus 2018 di Sekolah Dasar Negeri 1 kecamatan kedungpring kabupaten lamongan. Subyek penelitian adalah peserta didik sekolah dasar kelas 6 SDN Kedungpring yang berjumlah peserta didik sebanyak 40 orang kelas control dan 40 orang kelas eksperimen.

Desain penelitian yang digunakan adalah one-Group Pretest-Posttest Design, dimana pretest dilakukan sebelum adanya perlakuan (penggunaan media visual) dan posttest dilakukan setelah adanya perlakuan. Desain dari one-Group PretestPosttest Design menurut Sugiyono (2012) digambarkan sebagai berikut:
Keterangan :

$\mathrm{O}_{1}=$ Nilai Pretest (sebelum diberi media) $\mathrm{O}_{2}=$ Nilai Posttest (setelah diberi media)

$\mathrm{O}_{2}-\mathrm{O}_{1}=$ Pengaruh media terhadap variabel

Instrument yang digunakan adalah angket (kuesioner) digunakan untuk memperoleh data validitas kelayan media visual. Tes dalam bentuk soal untuk mengukur hasil belajar dan untuk memperoleh data tentang efektifitas media visual. Dokumentasi dapat berbentuk dokumen penting dari lokasi penelitian, foto atau gambar yang berkaitan dengan penelitian, data yang relevan dengan penelitian.

Teknik analisis data yang digunakan berupa data kualitatif dalam bentuk deskripsi yang nantinya akan digunakan dalam mendiskripsikan hasil penelitian serta didukung dengan data kuantitatif dalam bentuk angka yang fungsinya sebagai penguat data kualitatif. Analisis data yang digunakan pada penelitian ini digunakan untuk mengetahui kelayakan dan efektifitas media visual.

Hasil kelayakan dapat diukur dengan skala Likert dengan aturan pembobotan skor pada setiap butir pertanyaan. Adapun pembobotan butir pertanyaan menurut Riduwan (2010) adalah sebagai berikut:

\section{$\mathrm{O}_{1} \mathrm{X} \mathrm{O}_{2}$}




\begin{tabular}{|l|c|}
\hline \multicolumn{1}{|c|}{ Peringkat } & Skor \\
\hline Sangat Baik/ sangat setuju & 5 \\
\hline Baik/ setuju & 4 \\
\hline Cukup/ Ragu-Ragu & 3 \\
\hline Kurang/tidak setuju & 2 \\
\hline $\begin{array}{l}\text { Sangat kurang/ sangat tidak } \\
\text { setuju }\end{array}$ & 1 \\
\hline
\end{tabular}

Sedangkan untuk menghitung total skor pada setiap aspek dapat diukur dengan rumus persentase berikut :

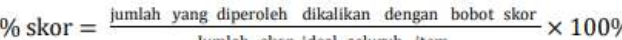
$=\frac{5 n+4 n+3 n+2 n+1 n}{5 N} \times 100 \%$

Keterangan :

$\mathrm{n}=$ Jumlah yang diperoleh

$\mathrm{N}=$ Jumlah item

Rumus persentase tersebut akan dikon-versikan kembali pada kategori kriteria skor yang akan dijelaskan pada tabel sebagai berikut:

\begin{tabular}{|l|l|}
\hline $\begin{array}{c}\text { Tingkat } \\
\text { Penilaian }\end{array}$ & \multicolumn{1}{|c|}{ Kategori } \\
\hline $0 \%-20 \%$ & $\begin{array}{l}\text { Sangat tidak setuju/tidak } \\
\text { layak }\end{array}$ \\
\hline $21 \%-40 \%$ & Tidak setuju/layak \\
\hline $41 \%-60 \%$ & Cukup/layak \\
\hline $61 \%-80 \%$ & Setuju/layak \\
\hline $\begin{array}{l}81 \% \\
100 \%\end{array}$ & Sangat setuju/sangat layak \\
\hline
\end{tabular}

Keefektifan media pembelajaran dapat diukur dengan Pretest dan Posttest. Hasil Pre-Posttest bertujuan untuk membandingkan kedua nilai tersebut apakah ada perbedaan yang signifikan. Menurut Arikunto (2007) perbedaan hasil dari Pre-Posttest diuji dengan menggu- nakan rumus uji-t, adapun rumusnya adalah sebagai berikut:

$$
t=\frac{M d}{\sqrt{\frac{\sum x^{2} d}{N(N-1)}}}
$$

Keterangan:

$\mathrm{Md}=$ mean dari perbedaan Pretest dan Posttest

$\sum x^{2} d=$ jumlah kuadrad deviasi

$\mathrm{N} \quad=$ objek pada sampel

d.b. = ditentukan dengan $\mathrm{N}-1$

\section{HASIL DAN PEMBAHASAN}

Proses pengembangan media visual dilakukan dengan menggunakan model pengembangan ADDIE yang terdiri dari lima tahapan, masing-masing tahapan akan dijelaskan sebagai berikut:

\section{A. Analisis}

Tahap analisis ini menghasilkan beberapa dokumen yang akan digunakan dalam pengembangan media visual yaitu: silabus dan RPP mata pelajaran PPKn, dokumen rendahnya hasil belajar mata pelajaran PPKn pada setiap Sekolah Dasar Negeri, dokumen kertas ulangan harian peserta didik mata pelajaran PPKn dan dokumen wawancara pada setiap pendidik PPKn Sekolah Dasar.

\section{B. Desain}

Tahap desain yang dikembangkan sesuai dengan tujuan pembelajaran mata pelajaran PPKn. 
Menyusun kembali silabus dan RPP sesuai dengan penggunaan media visual. Sistematika penyajian materi diprosentasekan sebanyak $50 \%$ teori dan $50 \%$ penggunaan media visual. Menyusun storyboard pengembangan media visual. Penyusunan instrument validasi pada ahli media, ahli materi, pendidik mata pelajaran PPKn. Penyusunan instrument tes tentang mata pelajaran PPKn pada peserta didik.

\section{Pengembangan}

Tahap pengembangan media visual terdiri dari lima tahapan:

1. mengumpulkan gambar atau foto yang sesuai dengan materi pembelajaran.

2. Melakukan validasi media visual pada ahli materi mata pelajaran PPKn dengan menggunakan angket yang hasilnya telah dikonversikan dengan peringkat 4 "BAIK" dengan kriteria penilaian tingkat penilaian 80\% kategori "LAYAK" dikarenakan penyajian materi sesuai dengan standar kompetensi, sehingga tidak perlu adanya revisi.

3. Melakukan validasi media visual pada ahli media dengan menggunakan angket yang hasilnya telah dikonversikan dengan peringkat 4 "BAIK" dengan kriteria penilaian tingkat penilaian
79\% kategori "LAYAK" dikarenakan penyajian materi sesuai dengan standar kompetensi, akan tetapi pemilihan gambar yang lebih disesuaikan dengan materi, gambar harus dicetak dengan kualitas yang baik dan jernih, harus diperhatikan perpaduan warna pada gambar, sehingga perlu adanya revisi dalam pemilihan gambar.

4. Melakukan validasi pada pendidik mata pelajaran PPKn dengan menggunakan angket yang hasilnya telah dikonversikan dengan peringkat 5 "SANGAT BAIK" dengan kriteria penilaian tingkat penilaian 93\% kategori "SANGAT LAYAK" dikarenakan penyajian materi sesuai dengan standar kompetensi, pendidik hanya meminta untuk setiap materi diberikan gambar cadangan agar lebih bervariasi dalam penggunaanya.

5. Uji coba kelompok validasi media dengan menggunakan angket yang hasilnya telah dikonversikan dengan peringkat 5 "SANGAT BAIK" dengan kriteria penilaian tingkat penilaian 95\% kategori "SANGAT LAYAK" dikarenakan penyajian materi sesuai dengan standar kompetensi, sehingga peserta didik termotivasi untuk 
belajar dan tidak perlu adanya revisi.

\section{Penerapan}

Penerapan media visual pada proses pembelajaran mata pelajaran PPKn kelas 6 Sekolah Dasar Negeri 1 Kedungpring diterapkan sesuai dengan naskah pembelajaran yang dikembangkan berbasis media. Penerapan media visual di dalam kelas mendapat respon yang cukup baik oleh peserta didik. Dilihat dari segi motivasi, peserta didik cukup termotivasi untuk bertanya dan mengikuti proses pembelajaran. Sedangkan dari segi efektivitas media visual, media visual dalam proses pembelajrannya nilai efektifitasnya cukup tinggi dilihat dari rata-rata nilai posttest meningkat sebanyak $78 \%$ dari nilai pretest dan nilai dokumen awal penelitian.

\section{E. Evaluasi}

Adapun hasil evaluasi internal terdiri dari masukan para ahli media, materi, guru mata pelajaran PPKN dan juga kelompok validasi. Semua hasil revisi telah divalidasi langsut pada saat selesai proses tahapan. Sedangkan hasil evaluasi eksternal berupa hasil uji coba kelompok besar yang nilai rata-rata posttest ada para range $80-98$ dari skala 100. Itu artinya tingginya tingkat efektifitas media visual yang digunakan dalam proses pembelajaran.

\section{KESIMPULAN}

Pengembangan media visual mata pelajaran PPKn dinilai efektif dan efisien, sehingga hasil tes belajar peserta didik meningkat dengan pesat. Meningkatnya hasil belajar peserta didik merupakan salah satu fakta baru yang dilahirkan pada dunia pendidikan bahwa pentingnya sebuah media pembelajaran di dalam kelas. Pengembangan media pembelajaran ini menggunakan model pembelajaran ADDIE yang prosesnya cukup mudah. Media visual merupakan salah satu media yang sangat digemari oleh peserta didik khususnya tingkat sekolah dasar, karena dengan belajar menggunakan media visual tersebut materi pembelajaran yang bersifat teoritis akan lebih mudah untuk dipahami.

\section{DAFTAR PUSTAKA}

Arikunto, S. (2007). Prosedur Penelitian: Suatu Pendekatan Praktik. Jakarta: PT Rineka Cipta.

Arsyad, A. (2008). Media Pembelajaran. Jakarta: PT. Raja Grafindo Persada.

DePorter, B. \&. (2001). Quantum Learning. New York: Dell Publishing.

DePorter, B. d. (2013). Quantum Learning: Membiasakan belajar nyaman dan 
Mulyatiningsih, E. (2012). Metode Penelitian Terapan Bidang Pendidikan. Bandung: Alfabeta.

Munadi, Y. (2013). Media pembelajaran "sebuah pendekatan baru". Jakarta Selatan: GP Press Group.

Nasution, S. (2003). Didaktik asas-asas mengajar. Jakarta: Bumi Aksara.

Oxford. (2003). Oxford advance learner's dictionary. Oxford: Oxford University Press.

Pribadi, B. A. (2009). Model Desain Sistem Pembelajaran. Jakarta: Dian Rakyat.

Riduwan. (2010). Skala Pengukuran Variabel-variabel Penelitian. Bandung: Alfabeta.
Smaldino, S. E., Lowther, D. L., \& Russell, J. D. (2008). Instructional Technology and Media for Learning. Ninth Edition. New Jersey: Pearson Education Inc.

Sugiyono. (2012). Metode Penelitian Kuantitatif Kualitatif dan $R \& D$. Bandung: Alfabeta.

Tegeh, M., \& Kirna, I. M. (2010). Metode penelitian pengembangan pendidikan. Singaraja: Universitas Pendidikan Ganesha.

Tileston, D. (2004). What every teacher should know about effective teaching strategies. California: Corwin Press. 